\title{
Flour production from shrimp by-products and sensory evaluation of flour-based products
}

\author{
Thiago Mendes Fernandes(1), João Andrade da Silva ${ }^{(2)}$, Ana Hermínia Andrade da Silva ${ }^{(3)}$, \\ José Marcelino de Oliveira Cavalheiro ${ }^{(4)}$ e Maria Lúcia da Conceição ${ }^{(2)}$
}

\begin{abstract}
(1)Universidade Federal da Paraíba (UFPB), Departamento de Farmácia, Cidade Universitária, s/no, CEP 58059-900 João Pessoa, PB. E-mail: thiagomfpictures@yahoo.com.br (2)UFPB, Departamento de Nutrição. E-mail: andradebr@yahoo.com.br, mluciacufpb@yahoo.com.br (3)UFPB, Departamento de Estatística. E-mail: anaherminia88@gmail.com ${ }^{(4)}$ UFPB, Departamento de Engenharia de Alimentos. E-mail: jmarcelin@uol.com.br
\end{abstract}

\begin{abstract}
The objective of this work was to evaluate the production of flour using by-products (cephalothorax) obtained from the shrimp (Litopenaeus vannamei) industry, and to perform a sensory analysis of shrimp flour-based products. Physicochemical and microbiological analyses on fresh cephalothorax and on manufactured flour were performed, as well as the determination of cholesterol content of this flour, and the sensorial evaluation of soup and pastry made with this flour. By the microbiological analyses, no pathogenic microorganism was detected in the samples. Physicochemical analyses of flour showed high levels of protein (50.05\%) and minerals (20.97\%). Shrimp cephalothorax flour showed high levels of cholesterol. The sensory evaluation indicated a good acceptance of the products, with satisfactory acceptability index ( $81 \%$ for soup, and $83 \%$ for pastry), which indicates that shrimp cephalothorax in the form of flour has a potential for developing new products.
\end{abstract}

Index terms: Litopenaeus vannamei, acceptance, cephalothorax, food technology.

\section{Produção de farinha de resíduo de camarão e avaliação sensorial de subprodutos formulados com base na farinha}

\begin{abstract}
Resumo - O objetivo deste trabalho foi avaliar a produção de um tipo de farinha de subprodutos (cefalotórax), obtidos da indústria de beneficiamento do camarão (Litopenaeus vannamei), e realizar uma análise sensorial de produtos formulados com a farinha. Foram feitas análises físico-químicas e microbiológicas do cefalotórax fresco e da farinha formulada, assim como a determinação do teor de colesterol dessa farinha e a avaliação sensorial de uma sopa e um pastel feitos com ela. Pelas análises microbiológicas, nenhum microrganismo patogênico foi encontrado nas amostras. As análises físico-químicas da farinha mostraram elevados teores de proteínas $(50,05 \%)$ e minerais $(20,97 \%)$. A farinha de cefalotórax de camarão apresentou elevado teor de colesterol. A avaliação sensorial indicou boa aceitação dos produtos, com índice de aceitabilidade satisfatório ( $81 \%$ para a sopa e $83 \%$ para o pastel), o que indica que o cefalotórax de camarão, na forma de farinha, tem potencial para o desenvolvimento de novos produtos.
\end{abstract}

Termos para indexação: Litopenaeus vannamei, aceitação, cefalotórax, tecnologia de alimentos.

\section{Introduction}

The large amount of by-products in the fishing industry has become an economic and environmental problem. Their use would avoid waste, and should reduce environmental pollution. Since in certain regions and social status of the country population suffer from nutritional deficiencies, the creation of alternative technologies to enable fish by-product management could bring consequences for the fight against hunger, besides promoting job creation and sustainable development. Thus, the utilization of shrimp industry by-products would bring environmental and health benefits, and could be highly important for use in food.
Alimentary raw materials discarded by the food industry often become sources of environmental contamination. In the fishing industry, waste is produced in high amounts, especially in small scale fishing, and there is a need to dispose of them without polluting the environment. According to De Holanda \& Maria Netto (2006), most of these products are derived from shrimp farming, which represents about $45 \%$ of the processed seafood, which are the disposal of carapace and exoskeleton, suggesting a need for utilization of this raw material. The development of technologies capable of transforming these by-products, preferentially into food, is necessary (Arvanitoyannis \& Kassaveti, 2008). 
Crustacean residues, depending on the species and type of processing, can amount to $85 \%$ of the initial weight (Ogawa et al., 2007). According to Cavalheiro et al. (2007), the low use of this by-product remains a serious problem, contributing to the overall cost of production. In the shrimp industry, the cephalothorax is usually discarded, which generates additional costs and reduces to profitability of the production system. From 2005 to 2007, approximately fifty thousand tons of beheaded shrimp were produced in Brazil. Residues continue to be discarded without any type of technological use (Ogawa et al., 2007). According to data surveyed by Guilherme et al. (2007), 33\% of all the shrimp production is discarded as garbage, and just a small amount of the cephalothorax is transformed into food. According to Damasceno et al. (2009), there is little research on the recovery of by-products generated by the shrimp industries, thus more studies on the development of new food products are required with both nutritional value and consumer acceptability, besides being an income generating product.

Shrimp is seafood considered to have a high cholesterol content. However, the concentration of fatty polyunsaturated acids is also high, which can lessen the noxious effects of cholesterol in the human organism (Bragagnolo \& Rodriguez-Amaya, 1997).

The objective of this work was to evaluate the production of flour using by-products (cephalothorax) obtained from the shrimp industry, and to perform a sensorial analysis of shrimp flour based products.

\section{Materials and Methods}

Shrimp (Litopenaeus vannamei) cephalothorax was obtained in the central market of João Pessoa, $\mathrm{PB}, \mathrm{Brazil}$, still in fresh state, and was transported in isothermal boxes and kept in refrigerator at $0^{\circ} \mathrm{C}$ in the Laboratory of Development of Fishing Products, Department of Food Chemistry and Technology, at Universidade Federal da Paraíba. The initial weight of cephalothorax used in this experiment was $800 \mathrm{~g}$. After washing, boiling, drying, grinding and sieving, the weight of the obtained flour was $120 \mathrm{~g}$, which corresponds to $15 \%$ yield in comparison to the initial weight. In the process of grinding and sieving, material loss occurred mainly due to flour adherence to the mill.

Analyses were carried out between January and June 2008. Before this period, preliminary tests were made to determine the best methodology to be used for flour production, physicochemical characterization, and cholesterol analysis.

Initially, by-products were subjected to pre-cleaning, and were washed in running water. Some impurities were manually removed. They were, then, sanitized with chlorinated water $\left(10 \mathrm{mg} \mathrm{L}^{-1}\right)$ in an ice bath for 20 min. After this procedure, the mixtures were boiled for a period of $15 \mathrm{~min}$. Boiling causes protein denaturation, facilitates the removal of moisture, and increases the drying rate, as well as helps to reduce the number of microorganisms present on cephalothorax surface.

Sample drying was accomplished in a kiln with forced-air circulation model Orion 520, (Fanem, São Paulo, SP, Brazil) at $70^{\circ} \mathrm{C}$ for 11 hours, which are the required temperature and time determined through drying curves for shrimp cephalothorax, according to Castro \& Pagani (2004). After drying, the samples were triturated in a hammer-type mill ( $2 \mathrm{hp})$, sifted in a $0.8 \mathrm{~mm}$ diameter mesh, and weighted. The resulting flour was placed in polyethylene containers, covered with plastic and aluminum film, and stored at $4{ }^{\circ} \mathrm{C}$.

The physicochemical analyses were conducted at the Laboratory of Food Analysis, Department of Food Chemistry and Technology, at Universidade Federal da Paraíba. The sample physicochemical characterization of in natura shrimp cephalothorax and of shrimp cephalothorax flour was done in triplicate. Determination of moisture was conducted using the gravimetric method, which is based on material drying until constant weight, in an oven, stabilized at $100 \pm 2^{\circ} \mathrm{C}$ (Zenebon \& Pascuet, 2005). Ashes were analysed using the gravimetric method (Zenebon \& Pascuet, 2005), based on carbonization of the sample on a hot plate, and followed by incineration of organic matter in an oven at $550 \pm 10^{\circ} \mathrm{C}$. Total lipids were analysed using the Soxhlet method (Zenebon \& Pascuet, 2005). Mineral contents were only determined in the flour samples, in triplicate. Iron and phosphorous contents were determined according to Ranganna (1976). Calcium content was determined according to Zenebon \& Pascuet (2005). Fiber contents were determined in the flour samples according to Kramer \& Ginkel (1952). Cholesterol content was determined in the flour through high-performance liquid chromatography (HPLC) (Bragagnolo \& Rodriguez-Amaya, 1997).

Microbiological analyses were performed in triplicate, in the Laboratory of Microbiology, Department of Nutrition, at Universidade Federal da Paraíba, using the methodology described by Vanderzant \& Splittstoesser 
(1992). The most probable number of thermotolerant coliforms and total coliforms, the presence of Salmonella sp., and a count of Staphylococcus positive coagulase were determined.

To test the production feasibility of shrimp cephalothorax flour, two products were elaborated: shrimp flavor soup and shrimp flavor pastry. Each product was evaluated by a panel of 51 untrained panelists, consisting of undergraduates, graduates, faculty members and staff of the Universidade Federal da Paraíba. The panelists who participated in the sensory evaluation were accustomed consumers of shrimp. The recruitment of judges was made in advance. Therefore, a questionnaire for the selection of judges was prepared, and presented with a consent form authorizing their voluntary participation in the survey. They were given a complete and detailed explanation of the nature of the research, explaining its aims, methods, anticipated benefits, potential risks and discomfort that this might entail. This study was approved by the Ethics Committee for Research, Health Sciences Center, Universidade Federal da Paraíba (Protocol No. 0264).

In the sensorial evaluation tests, the affective method was used, with an acceptance test for the quality of the final product for the attributes appearance, aroma, color, flavor, as well as a global evaluation, using a nine-point scale ranging from: "liked very much" (9) to "disliked very much" (1) (Stone \& Sidel, 1993). In addition, the purchase intention was evaluated using a five-point hedonic scale ranging from: "would buy" (5) to "would never buy" (1).

The results were submitted to statistical tests with the aid of the free R software, version 2.8.1 (R Foundation for Statistical Computing, Vienna, Austria). The association between the effect of the variables and the attributed scores was verified using the Fisher exact test at 5\% probability (Siegel, 1975).

\section{Results and Discussion}

The drying process altered the component percentages of "in natura" raw material because with the reduction of water amount, there was an increase of total lipids, and of proteins and ash concentrations (Table 1). After drying, moisture was reduced to a value close to that found by Castro \& Pagani (2004), which was of $5 \%$ in shrimp flour. Ash content of "in natura" cephalothorax was close to that found by
Assunção \& Pena (2007) in dry Pandalus borealis shrimp head residue (22.01\%).

In a study on the centesimal composition and on fatty acids profile of fresh water shrimp, Castro \& Pagani (2004) found $0.92 \%$ fat content in fresh shrimp cephalothorax dried at $50^{\circ} \mathrm{C}$, which is lower than that found in our research for raw shrimp cephalothorax. Furuya et al. (2006) found $1.5 \%$ of total lipids in whole freshwater Macrobrachium amazonicum prawns. These results were higher than those obtained by Bragagnolo \& Rodriguez-Amaya (1997), who found values below $1 \%$ in the fillets of several shrimp species. However, this lower value is observed because shrimp fat is mainly stored in the hepatopancreas, located in the cephalothorax. According to Rosa \& Nunes (2004) and Sriket et al. (2007), differences in the centesimal composition are attributed to several factors such as the species analyzed, growth rate, age, degree of sexual maturation, and feeding.

Protein content in the flour was lower than that found by Lima et al. (2007), which was $66.01 \%$ for shrimp cephalothorax flour. Sriket et al. (2007) found 18.8\% protein content in shrimp fillets, a value close to that found in fresh cephalothorax examined in the present research. This indicates that shrimp cephalothorax can be used as an alternative source of protein in comparison to fillet. According to Brasileiro et al. (2012), the protein concentrate obtained from shrimp by-products can be used as a protein supplement in the formulation of food for human consumption. Heu et al. (2003) suggest that products obtained from processing shrimp waste can serve as a suitable source of protein and flavoring, which can be used in food formulations, mainly due to their content of free amino acids. Castro \& Pagani (2004) note that the shrimp head has a

Table 1. Composition (mean \pm standard deviation) of fresh shrimp cephalothorax and flour.

\begin{tabular}{lcc}
\hline Constituent & $\begin{array}{c}\text { Fresh shrimp } \\
\text { cephalothorax }\end{array}$ & $\begin{array}{c}\text { Shrimp cephalothorax } \\
\text { flour }\end{array}$ \\
\hline Moisture (\%) & $75.47 \pm 0.43$ & $5.77 \pm 0.07$ \\
Ashes (\%) & $4.35 \pm 0.28$ & $20.97 \pm 1.20$ \\
Crude protein (\%) & $14.75 \pm 0.79$ & $50.05 \pm 1.81$ \\
Total lipids (\%) & $1.10 \pm 0.098$ & $9.32 \pm 1.33$ \\
Fibers & $*$ & $17.84 \pm 1.34$ \\
Phosphorous $\left({\left.\mathrm{g} 100 \mathrm{~g}^{-1}\right)}^{\text {Iron }\left(\mathrm{mg} 100 \mathrm{~g}^{-1}\right)}\right.$ & - & $1.61 \pm 0.03$ \\
Calcium $\left(\mathrm{g} 100 \mathrm{~g}^{-1}\right)$ & - & $8.79 \pm 0.29$ \\
Cholesterol $\left({\left.\mathrm{mg} 100 \mathrm{~g}^{-1}\right)}\right.$ & - & $10.03 \pm 0.39$ \\
\hline
\end{tabular}

*Uncertain. 
high protein value and propose its utilization in the enrichment of various processed foods.

Fibers in the shrimp cephalothorax are composed of chitin, and are responsible for the high fiber content in the resulting flour. Randriamahatody et al. (2011) estimated $16 \%$ chitin in dried cephalothorax of Peaneus monodon, which is similar in value to that found for shrimp cephalotorax flour in the present research.

Phosphorus content found in the flour (Table 1) was higher than that found by Guilherme et al. (2006)

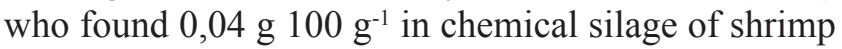
cephalothorax. There appears to be no reported data on iron content in shrimp cephalothorax. Fanimo et al.

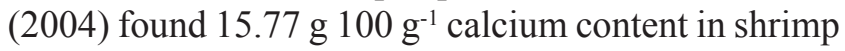
cephalothorax flour, which is higher than that found in the present research.

Cephalothorax flour of shrimps showed high levels of cholesterol. No other reports of cholesterol levels in flour shrimp heads were found in the literature. Araújo et al. (2012) found $26.1 \mathrm{mg} 100 \mathrm{~g}^{-1}$ in cholesterol average content in shrimp fillets. According to Santos et al. (2007), nutrition, genetics, sex, reproductive stage, size, environmental variations and forms of creation, among other factors, determine the chemical composition of a particular species. Cholesterol content in the flour is larger than that expected from fresh samples due to the loss of water during the drying process. According to Bragagnolo \& Rodriguez-Amaya (1997), the high cholesterol content in shrimps is compensated by the high levels of polyunsaturated fatty acids that act as preventive elements of cardiovascular diseases.

According to the results obtained in the proximate analysis, it was noted that the shrimp cephalothorax flour is rich in protein and minerals. Since much of the country's population suffers from nutritional deficiencies, creating alternative technologies that allow the use of waste from shrimp farming can bring results in the fight against hunger, as well job creation and sustainable development. Moreover, as large amount of by-products of shrimp farming is still wasted and causes economic and environmental problems, the utilization of shrimp waste would reduce environmental pollution.

The results obtained in the microbiological analysis (Table 2) show that the produced flour is within the acceptable standards for human consumption, and is in agreement with the resolution RDC No. 12 of the Brazil's national sanitary surveillance agency (Agência
Nacional de Vigilância Sanitária, 2001). According to this resolution, in fish-derived products, refrigerated and precooked fish, the presence of Salmonella should not be detected because it is a potentially pathogenic bacteria. As for the research of thermotolerant coliforms, the values found are within the norms compared with precooked fish-derived products (maximum of $10^{2}$ MPN $\mathrm{g}^{-1}$ ) (Agência Nacional de Vigilância Sanitária, 2001).

As for the total coliforms, the legislation does not establish limits for fish, but its analysis is important since they are related with the hygienic-sanitary quality. However, according to Agnese et al. (2001), in the case of values above $10^{2} \mathrm{MPN} \mathrm{g}^{-1}$ in fish meat, there is a need for a more rigid control, regarding hygiene in the production and commercialization of this product. The values observed for all samples were far below this limit, evidencing a good hygienic-sanitary quality during processing (Table 2 ). According to these results, the product was considered suitable for consumption because it was within the recommended values by legislation.

By the global acceptance test on the obtained results, pastries elaborated with shrimp cephalothorax flour had a good acceptance, with average scores above 7 (which corresponds to the concept "liked moderately") (Table 3). Soup also showed satisfactory sensory characteristics, which is an indication that the developed

Table 2. Microbiological analysis of fresh shrimp cephalothorax without hygienization (CSH), hygienized fresh shrimp cephalothorax $(\mathrm{CCH})$ and shrimp cephalothorax flour (FCC).

\begin{tabular}{lccc}
\hline Microorganisms & CSH & CCH & FCC \\
\hline Total coliforms (MPN g-1) & $<3.0$ & $<3.0$ & $<3.0$ \\
Thermotolerant coliforms $\left(\mathrm{MPN} \mathrm{g}^{-1}\right)$ & $<3.0$ & $<3.0$ & $<3.0$ \\
Staphylococcus positive coagulase $\left(\mathrm{CFU} \mathrm{g}^{-1}\right)$ & $<1.0$ & $<1.0$ & $<1.0$ \\
Salmonella sp. (in $25 \mathrm{~g})$ & Absent & Absent & Absent \\
\hline
\end{tabular}

$\mathrm{MPN} \mathrm{g}^{-1}$ (more probable number per gram); $\mathrm{CFU} \mathrm{g}^{-1}$ (colony forming units per gram).

Table 3. Summary of the descriptive statistics of the global acceptance test for shrimp-flavor soup and shrimp-flavor pastry elaborated from shrimp cephalothorax flour.

\begin{tabular}{lcccccc}
\hline Product & $\begin{array}{c}\text { Number of } \\
\text { observation }\end{array}$ & $\begin{array}{c}\text { Average } \\
\text { scores }\end{array}$ & $\begin{array}{c}\text { Standard } \\
\text { deviation }\end{array}$ & $\begin{array}{c}\text { Min. } \\
\text { score }\end{array}$ & $\begin{array}{c}\text { Max. } \\
\text { score }\end{array}$ & $\begin{array}{c}\text { Acceptability } \\
\text { index (\%) }\end{array}$ \\
\hline Soup & 51 & 7.29 & 0.98 & 4 & 9 & 81.00 \\
Pastry & 51 & 7.43 & 0.87 & 5 & 9 & 82.56 \\
\hline
\end{tabular}

Pesq. agropec. bras., Brasília, v.48, n.8, p.962-967, ago. 2013 DOI: 10.1590/S0100-204X2013000800022 
products can be absorbed by the consumption market. The acceptability index of both products is considerably higher than the $70 \%$ considered satisfactory according to the statistical analysis of Teixeira et al. (1987).

The good acceptance of products can be confirmed, as the average score is located between "possibly would buy" and "would buy" (Figure 1). It should be emphasized that the acceptance or preference for a product are linked to habits and cultural patterns, as well as individual sensibility, age, hygiene, consumption place, and number and type of companions at the moment of consuming the product, among other aspects.

Flavor judgment was influenced by the age of the participants, and the overall assessment was influenced by the consumption of shrimp (Table 4). In

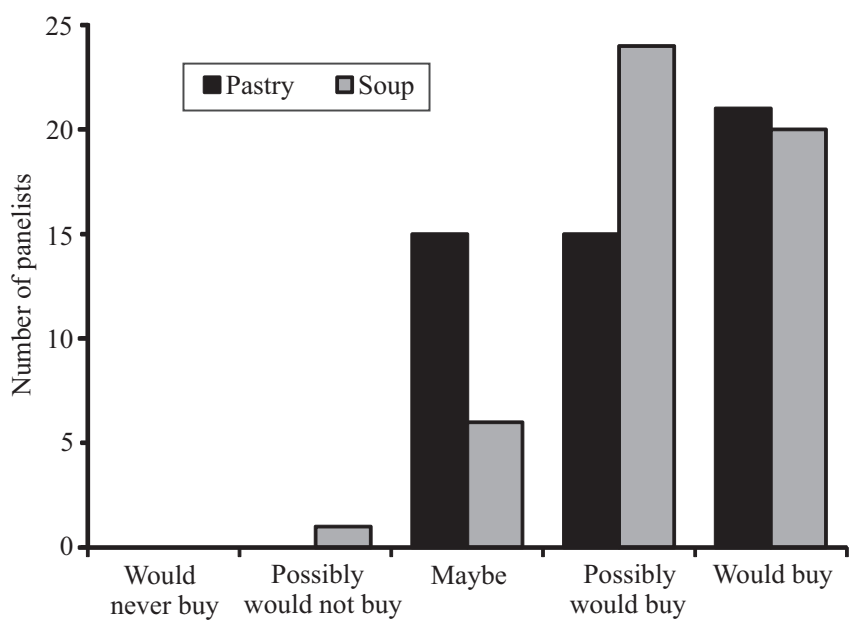

Figure 1. Purchase intention by the appraisal of soup and pastry elaborated from shrimp cephalothorax flour.

Table 4. Association between the variables of the sensory analysis of pastries elaborated from shrimp cephalothorax flour.

\begin{tabular}{ll}
\hline Homogeneity test & $\mathrm{p}$-value \\
\hline Age vs. appearance & 0.1550 \\
Age vs. color & 0.0760 \\
Age vs. aroma & 0.9026 \\
Age vs. flavor & $0.0137^{*}$ \\
Age vs. global evaluation & 0.1251 \\
Average consumption vs. appearance & 0.3456 \\
Average consumption vs. color & 0.5039 \\
Average consumption vs. aroma & 0.0651 \\
Average consumption vs. flavor & 0.2274 \\
Average consumption vs. global evaluation & $0.0254^{*}$ \\
\hline
\end{tabular}

*Significant by Fisher's test at 5\% probability. other results, no significant difference was found. In addition, no strong correlation could be found in the sensory analysis of the soup results.

As to scores, people who affirmed to consume most shrimp were those who attributed the best scores. Also, the younger judges were those who attributed the best scores in the global evaluation of pastries, which could be explained by their habit of consuming savory fries.

\section{Conclusions}

1. It is feasible to use shrimp (Litopenaeus vannamei) by-products in the production of flour.

2. Flour of shrimp cephalothorax has a high protein content and minerals, as well as a high content of cholesterol.

3. The good acceptance of pastry and soup shows that the cephalothorax of shrimp in the form of flour has a potential for developing new products.

\section{Acknowledgements}

To Conselho Nacional de Desenvolvimento Científico e Tecnológico (CNPq), for financial support.

\section{References}

AGÊNCIA NACIONAL DE VIGILÂNCIA SANITÁRIA. Resolução RDC $n^{\circ} 12$, de 02 de janeiro de 2001. Aprova o Regulamento Técnico sobre padrões microbiológicos para alimentos. Diário Oficial [da] República Federativa do Brasil, 10 jan. 2001.

AGNESE, A.P.; OLIVEIRA, V.M. de; SILVA, P.P.O. da; OLIVEIRA, G.A. de. Contagem de bactérias heterotróficas aeróbias mesófilas e enumeração de coliformes totais e fecais, em peixes frescos comercializados no Município de Seropédica - RJ. Revista Higiene Alimentar, v.15, p.67-70, 2001.

ARAÚJO, D.F. de S.; SILVESTRE, D.D.; DAMASCENO, K.S.F. da S.C.; PEDROSA, L.F.C.; SEABRA, L.M.'A.J. Composição centesimal e teor de colesterol do camarão branco do Pacífico. Ciência Rural, v.42, p.1130-1133, 2012. DOI: 10.1590/ S0103-84782012000600029.

ARVANITOYANNIS, I.S.; KASSAVETI, A. Fish industry waste: treatments, environmental impacts, current and potential uses. International Journal of Food Science and Technology, v.43, p.726-745, 2008. DOI: 10.1111/j.1365-2621.2006.01513.x.

ASSUNÇÃO, A.B.; PENA, R. da S. Comportamento higroscópico do resíduo seco de camarão-rosa. Ciência e Tecnologia de Alimentos, v.27, p.786-793, 2007. DOI: 10.1590/ S0101-20612007000400018. 
BRAGAGNOLO, N.; RODRIGUEZ-AMAYA, D. Otimização da determinação de colesterol por CLAE e teores de colesterol, lipídios totais e ácidos graxos em camarão rosa (Penaeus brasiliensis). Ciência e Tecnologia de Alimentos, v.17, p.275-280, 1997. DOI: 10.1590/S0101-20611997000300016.

BRASILEIRO, O.L.; CAVALHEIRO, J.M.O.; PRADO, J.P. de S.; ANJOS, A.G. dos; CAVALHEIRI, T.T.B. Determination of the chemical composition and functional properties of shrimp waste protein concentrate and lyophilized flour. Ciência eAgrotecnologia, v.36, p.189-194, 2012. DOI: 10.1590/S1413-70542012000200007.

CASTRO, A.A.; PAGANI, G.D. Secagem e composição química da cabeça de camarão (Litopenaeus vannamei Boone) a diferentes temperaturas. Revista Brasileira de Produtos Agroindustriais, v.6, p.123-129, 2004.

CAVALHEIRO, J.M.O.; SOUZA, E.O. de; BORA, P.S. Utilization of shrimp industry waste in the formulation of tilápia (Oreochromis niloticus Linnaeus) feed. Bioresource Technology, v.98, p.602-606, 2007. DOI: 10.1016/j.biortech.2006.02.018.

DAMASCENO, K.S.F.S.C.; ANDRADE, S.A.C.; STAMFORD, T.L.M. Aproveitamento do resíduo de camarão. Boletim do Ceppa, v.27, p.213-224, 2009.

DE HOLANDA, H.D.; MARIA NETTO, F. Recovery of components from shrimp (Xiphopenaeus kroyeri) processing waste by enzymatic hydrolysis. Journal of Food Science, v.71, p.298-303, 2006. DOI: 10.1111/j.1750-3841.2006.00040.x.

FANIMO, A.O.; ODUGUWA, B.O.; ODUGUWA, O.O.; AJASA, O.Y.; JEGEDE, O. Feeding value of shrimp meal for growing pigs. Archivos de Zootecnia, v.53, p.77-85, 2004.

FURUYA, W.M.; HAYASHI, C.; SILVA, A.B.M. da; SANTOS JÚNIOR, O. de O.; SOUZA, N.E. de; MATSUSHITA, M.; VISENTAINER, J.V. Composição centesimal e perfil de ácidos graxos do camarão-d'água-doce. Revista Brasileira de Zootecnia, v.35, p.1577-1580, 2006. DOI: 10.1590/ S1516-35982006000600001.

GUILHERME, R.F.; CAVALHEIRO, J.M.O.; SOUZA, P.A.S. Caracterização química e perfil aminoácidico da farinha de silagem de cabeça de camarão. Ciência e Agrotecnologia, v.31, p.793-797, 2007. DOI: $10.1590 /$ S1413-70542007000300028.

HEU, M.S.; KIM, J.S.; SHAHIDI, F. Components and nutritional quality of shrimp processing by-products. Food Chemistry, v.82, p.235-242, 2003. DOI: 10.1016/S0308-8146(02)00519-8.

KRAMER, J.H. van de; GINKEL, L. van. Rapid determination of crude fiber in cereal. Cereal Chemistry, v.29, p.239-251, 1952.

LIMA, S.B.P. de; RABELLO, C.B.-V.; DUTRA JUNIOR, W.M.; LUDKE, M. do C.M.M.; COSTA, F.G.P. Avaliação nutricional da farinha da cabeça de camarão marinho (Litopenaeus vannamei) para frangos de corte. Revista Caatinga, v.20, p.35-39, 2007.

OGAWA, M.; MAIA, E.L.; FERNANDES, A.C.; NUNES, M.L.; OLIVEIRA, M.E.B. de; FREITAS, S.T. Resíduos do beneficiamento do camarão cultivado: obtenção de pigmentos carotenóides. Ciência e Tecnologia de Alimentos, v.27, p.333-337, 2007. DOI: 10.1590/S0101-20612007000200022.

RANDRIAMAHATODY, Z.; SYLLA, K.S.B.; NGUYEN, H.T.M.; DONNAY-MORENO, C.; RAZANAMPARANY, L.; BOURGOUGNON, N.; BERGÉ, J.P. Proteolysis of shrimp by-products (Peaneus monodon) from Madagascar. CYTA - Journal of Food, v.9, p.220-228, 2011. DOI: 10.1080/19476337.2010.518250.

RANGANNA, S. Manual of analysis of fruit and vegetable products. Tata: Mcgraw-Hill, 1976. 634p.

ROSA, R.; NUNES, M.L. Nutritional quality of red shrimp, Aristeus antennatus (Risso), pink shrimp, Parapenaeus longirostris (Lucas), and Norway lobster, Nephrops norvegicus (Linnaeus). Journal of the Science of Food and Agriculture, v.84, p.89-94, 2004. DOI: $10.1002 /$ jsfa.1619.

SANTOS, F.L. dos; AZEREDO, V.B. de; MARTINS, A.S.A. Efeito do fornecimento de ração complementada com semente de linhaça sobre os macronutrientes e colesterol em tecidos de camarões da Malásia (Macrobrachium rosenbergii). Ciência e Tecnologia de Alimentos, v.27, p.851-855, 2007. DOI: 10.1590/ S0101-20612007000400027.

SIEGEL, S. Estatística não-paramétrica para ciências do comportamento. São Paulo: McGraw-Hill, 1975. 350p.

SRIKET, P.; BENJAKUL, S.; VISESSANGUAN, W.; KIJROONGROJANA, K. Comparative studies on chemical composition and thermal properties of black tiger shrimp (Penaeus monodon) and white shrimp (Penaeus vannamei) meats. Food Chemistry, v.103, p.1199-1207, 2007. DOI: 10.1016/j. foodchem.2006.10.039.

STONE, H.; SIDEL, J. Sensory evaluation practices. $2^{\text {nd }}$ ed. New York: Academic Press, 1993. 338p.

TEIXEIRA, E.; MEINERT, E.M.; BARBETTA, P.A. Análise sensorial de alimentos. Florianópolis: Ed. da UFRS, 1987. $180 \mathrm{p}$.

VANDERZANT, C.; SPLITTSTOESSER, D.F. Compendium of methods for the microbiological examination of foods. $3^{\text {rd }} \mathrm{ed}$. Washington: American Public Health association, 1992. 1250p.

ZENEBON, O.; PASCUET, N.S. (Coord.). Métodos físico-químicos para análise de alimentos. 4.ed. Brasília: Ministério da Saúde, 2005. 1018p.

Received on August 24, 2011 and accepted on July 3, 2013 